Journal of Southeast Asian

\title{
Book Review: The American Dream in Vietnamese by Nhi T. Lieu
}

Malaphone Phommasa

University of California, Santa Barbara,mphommas@gmail.com

\section{Recommended Citation}

Phommasa, Malaphone (2011) "Book Review: The American Dream in Vietnamese by Nhi T. Lieu," Journal of Southeast Asian American Education and Advancement. Vol. 6 : Iss. 1, Article 15.

DOI: $10.7771 / 2153-8999.1031$

Available at: https://docs.lib.purdue.edu/jsaaea/vol6/iss1/15

This document has been made available through Purdue e-Pubs, a service of the Purdue University Libraries. Please contact epubs@purdue.edu for additional information.

This is an Open Access journal. This means that it uses a funding model that does not charge readers or their institutions for access. Readers may freely read, download, copy, distribute, print, search, or link to the full texts of articles. This journal is covered under the CC BY-NC-ND license. 


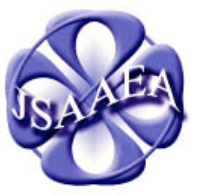

Volume 6 (2011)
Journal of Southeast Asian American Education \& Advancement

WWw.JSAAEA.org
A peer-reviewed scholarly journal published by the National Association for the Education \& Advancement of Cambodian, Laotian, and Vietnamese Americans (NAFEA)

\title{
Book Review
}

\section{Lieu, N. T. (2011). The American Dream in Vietnamese. Minneapolis, MN: University of Minnesota Press. 216 pp. \$22.50 (Paperback). ISBN: 978-0-8166- 6570-9.}

\author{
Reviewed by \\ Malaphone Phommasa \\ University of California, Santa Barbara
}

The American Dream in Vietnamese thoughtfully crafts together an illustration of the Vietnamese community, from their migration history to the creation of their new cultural identities in Orange County, California. Combining historical, anthropological, and sociological research traditions, Nhi T. Lieu provides an in-depth examination of the cultural productions of leisure and entertainment. These aspects of the Vietnamese community have largely been overlooked by scholars. The author demonstrates how beauty contests, live music variety shows, and videos of these variety shows are contributing to the transformations of what it means to be Vietnamese. Determined to move beyond the prevailing views and research of Vietnamese Americans as "despondent war-torn refugees," Lieu situates her work alongside the works of other important scholars, including Yen Lê Espiritu and Linda Trinh Võ, who are leading researchers on the cultural and social developments of the Vietnamese community postmigration. As a preview for the rest of the book, the author reveals her personal connection to Little Saigon and the variety shows as a Vietnamese American teenager who grew up in Southern California during the development of the community in the 1980's. Her intimate connection with this ethnic enclave and membership in the larger Vietnamese diasporic community sparked her desire to fully understand the world and culture around her.

The title of the introductory chapter, Private Desires on Public Display, nicely captures Lieu's well-crafted work on the reconstruction of Vietnamese American cultural and ethnic identity in symbolic Little Saigon. Longstanding desires and nostalgia of the homeland have led to the production of various leisure and entertainment avenues that publicly and strategically suggest to mainstream society that Vietnamese Americans have risen to middle-class status and embraced the role of consumers in a capitalist society. Tied to these productions are gender, class, and ethnic dimensions that require careful examination along with a critical analysis of what kinds of images are selectively displayed by the producers and also constrained by the beliefs of the community. The author, for the most part, does a thorough job of discussing each of these dimensions within each chapter.

\section{(c)}

SOBRERIGHISRESERVED Readers are free to copy, display, and distribute this article, as long as the work is attributed to the author(s) and the Journal of Southeast Asian American Education \& Advancement, it is distributed for noncommercial purposes only, and no alteration or transformation is made in the work. More details of this Creative Commons license are available at http://creativecommons.org/licenses/by-nc-nd/3.0/. All other uses must be approved by the author(s) or JSAAEA. 
Chapter 1 established the U.S. presence in Vietnam as more than a military imposition. Not only were U.S. corporations in control of much of Vietnam's economy, American culture also permeated elite Vietnamese society. Those in the cities, especially Saigon, were influenced by Western art, music, literature, film, and other habits. Many who worked for large American enterprises or the U.S. government were able to reclaim these positions or offered positions as counselors or mediators during the resettlement process. Therefore, there were a small number of Vietnamese who migrated as "immigrants" rather than "refugees." As the author mentions, this is largely overlooked in history. Lieu argues for the importance of considering class when studying the Vietnamese community. She contends that this elite society regains their position once settling in the U.S. and becomes the "cultural gatekeepers of the Vietnamese diaspora" (p. 2). Thus, the U.S. involvement in Vietnam left a lasting impact on Vietnamese and Vietnamese Americans that carried on into the diaspora.

The second chapter recounts the development of Little Saigon, a business district in the City of Westminster in Orange County, which is home to more than 200,000 Vietnamese Americans. Born out of a desire to recreate the familiar, Little Saigon was created through the collective efforts of the Vietnamese community. Although now popularly considered a Vietnamese community, this development did not come without struggle. In her research, Lieu discovered the significant economic and social role ethnic Chinese immigrants from Vietnam played in the creation of Little Saigon and Vietnamese ethnic identity. As a result of the Chinese colonial presence in Vietnamese history, many ethnic Chinese who held economic influence in Vietnam carried their influence over in the rebuilding of Little Saigon. One such player was Frank Jao, an ethnic Chinese immigrant from Vietnam, who was instrumental in developing much of the territory that constitutes Little Saigon. One description comes into question regarding Jao in this book. Lieu strictly refers to Jao as ethnically Chinese, though an Orange County Register article from September 30, 2006 only alludes to his mother's Chinese ethnicity with no mention of his father's. Jao's father's Vietnamese ethnicity would not justify the argument of the strict divide between his Chinese heritage and the Vietnamese community that Lieu makes in the chapter. Questions regarding Jao's ethnic loyalties became a point of contention when he attempted to include more Chinese-influenced or pan-Asian architecture, which the grassroots protests of the Vietnamese community defeated. The community's tension with Jao was only one of many cases, as a disproportionate number of the Vietnamese businesses were owned by Chinese émigrés. Therefore, in advocating for a distinct ethnic and cultural identity from the Chinese, Little Saigon "has become a place that nurtures political, social, cultural, and emotional needs - essentially, a place that replaced the lost nation" for Vietnamese Americans (p. 57). This chapter impressively explains the history of Little Saigon, rooted back to the history of tension between ethnic Chinese and Vietnamese in Vietnam. Lieu's in-depth description of the birth of Little Saigon should propel the diasporic community towards a larger appreciation for the cultural stronghold it has become for all Vietnamese Americans.

In Chapter 3, Lieu presents the ao dai beauty pageants as a means of expressing the nostalgia of the homeland as well as serving as a connection to the present. Emphasized is the essential role that women play in these public representations of the Vietnamese community. A blend of the traditional and modern, along with a middle-class bourgeois demeanor, women in the ao dai pageants are publicly displaying the "American Dream" or private desires of Vietnamese Americans. A strength of this chapter lies in Lieu's critical analysis of the ao dai beauty pageants. The author moves beyond the cultural significance of these pageants and examines the gender biases that exist within the community. Engaging in a more feminist stance, 
Lieu insightfully discusses the contradictions that appear in these pageants. Although women are seen to hold a dominant role in portraying the imagined unity of the nation, their voices are often silenced. Not given a role to speak until after three rounds of outfit modeling in the ao dai pageants, women are also traditionally kept out of the political arena. Though clearly important to affirming Vietnamese identity, women are merely used for visual pleasure. Rather than being seen as active creators of Vietnamese culture, they are used as tools constrained by the community's ideals.

Chapter 4's discussion of Vietnamese live music variety shows brings in all of the gender, class, and ethnic dimensions that Lieu had asserted was part of the construction of Vietnamese American identity. Here, all dimensions are thoroughly discussed and examined in great depth as compared to the other chapters. This comprehensive examination of the live music shows was a perfect example to weave all of the previous chapters together. An interesting topic that is mentioned as part of this analysis is the growing number of plastic surgeries among males and females within the Vietnamese population. Lieu argues for the influence of Hollywood celebrities and Vietnamese entertainers on this growing trend, but the community has also begun to blend Vietnamese and Western standards of beauty to create a new hybrid conception of Vietnamese American beauty. Although Lieu's research found a vast majority of people believe performers should use plastic surgery as a means of building more confidence for the stage, the author interestingly suggests plastic surgery as a possible method of healing scars of the past by transforming into a new identity. Although this is a valid argument due to the immigration history of Vietnamese Americans, there does not appear to be enough evidence presented within the Vietnamese community to make this strong claim. This emerging trend should be a study that Lieu explores in greater depth to provide an understanding of the plastic surgery phenomenon among females and males within the Vietnamese American community.

As powerful as Little Saigon is as a cultural-maker for the Vietnamese diasporic population, it does not exist in isolation. The concluding chapter sets the stage for future studies on the effects of globalization on the Vietnamese American community. Once the U.S. and Vietnam restored political and economic relations, goods and material culture were passing between borders in mass quantities. Although these transnational flows of material culture are seen as a threat to the older Vietnamese population, a younger generation of Vietnamese Americans seems to have readily accepted these cultural commodities. How will Vietnamese Americans continue to define what it means to be "Vietnamese?" Will newer generations become more influenced by Vietnam itself? The immigrant and refugee populations are tightly bounded by staunch anti-communist beliefs, but will these feelings hold for the succeeding generations who will be further removed from history? These are interesting topics to explore as cultural forms become increasingly transnational.

A number of other questions emerged after reading The American Dream in Vietnamese. For instance "To whom does the American Dream really apply?" Is it only the population of Vietnamese who are able to personally experience the wonders of Little Saigon, those who are fortunate enough to live in a well-established ethnic enclave? Does this cut across all social classes, as we noted the middle-class pursuits? And what about the second generation and beyond? Do these dreams apply to those who are not personally rooted in the united fight against communism? Although Lieu is careful to mention the generational and class differences that exist within this diasporic population, the book still appears to suggest this capitalist consumer, bourgeois-chasing American Dream applies to the general Vietnamese immigrant and refugee population. These assertions are drawn from the productions of the "cultural gatekeepers," a title 
Lieu designated to émigrés from elite Vietnamese society in Chapter 1. Therefore, is it appropriate to believe this American Dream applies to all Vietnamese Americans? It is not quite clear who the cultural and ethnic identities that have been created in the diaspora are intended to apply to.

Contributing to this belief are data from the web surveys collected by the author. One conclusion claimed that the second generation were critical of the media forms that were so beloved by the diasporic population and considered themselves "peripheral and resistant" ( $p$. 125) to these representations of Vietnamese identity. Interestingly, the majority of criticisms presented by Lieu refer to an over-Westernization of Vietnamese icons. They have become increasingly resentful of the hegemony the diasporic media has had on views of beauty and behavior, thus turning to cultural goods coming from Vietnam as "authentic." Rumbaut's (1995) assertion that the "legacy of war will likely recede in practical importance" (p. 239) for second generation Southeast Asians does not appear relevant in Lieu's findings. However, it can also be argued that the acceptance of material culture flowing in from Vietnam is just another form of teenage resistance to their parents' generation. They may be defining for themselves what it means to be Vietnamese Americans.

The methodology employed by Lieu to obtain her web surveys weakens the arguments made with the data. Over the course of three years, 43 completed surveys and 83 partial surveys were returned to the author. That is a seemingly low number for the amount of time allotted to the collection and there was also little mention of where these surveys were distributed. Another inconsistency apparent in the sample was the characteristics of the respondents. The exact number of male and female participants was not provided. The author notes that the overwhelming majority were male students or professionals between the ages of 18-35 years old who were proficient in the English language. This sample already provides an imbalanced view of identity, beauty and community.

Nevertheless, Lieu's scholarly work is an important contribution to the field of Asian American studies as an examination of the cultural productions of leisure and entertainment that is commonly disregarded when studying newer immigrant populations. Moving away from a focus on the psychological adjustments of refugees and immigrants, which characterizes much of the literature on Southeast Asian Americans, this study provides a critical analysis of the reconstruction of Vietnamese culture and identity. As the author states, "Neither static nor pure, Vietnamese culture has always been in flux - an unstable process that is always in motion" (p. 134). This quote captures well the transformations experienced by Vietnamese identities in an increasingly globalized world. Lieu's work is further important because it delves into aspects of American and Vietnamese history that is often overlooked or purposefully forgotten due to the tenuous history of U.S.-Vietnamese relations. I highly suggest this book to those interested in the Vietnamese population or studying media forms as carriers of culture and identity. I believe this book would serve well in any course that is prepared to assume a critical perspective on what the construction of culture and identity means for an ethnic group.

\section{References}

Gittelsohn, J. (2006, September 30). Little Saigon 'Godfather' sets sights on Vietnam. The Orange County Register. Retrieved from http://articles.ocregister.com/2006-0930/business/24752113_1_jeffrey-brody-vietnamese-refugee-bridgecreek-development 
Rumbaut, R.G. (1995). Vietnamese, Laotian, and Cambodian Americans. In P. G. Min (Ed.), Asian Americans: Contemporary trends and issues. Thousand Oaks, CA: Sage Publications, Inc.

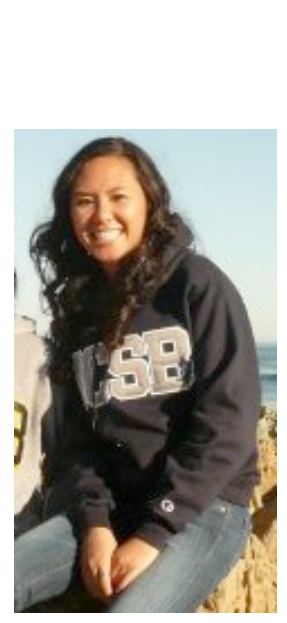

\section{About the Author}

Malaphone Phommasa is a graduate student in the Gevirtz Graduate School of Education at the University of California, Santa Barbara. Her emphasis is in Cultural Perspectives \& Comparative Education. Currently, her research examines the influences on the development of educational aspirations of second-generation Laotian American college students, with particular attention paid to the role of their refugee parents. 


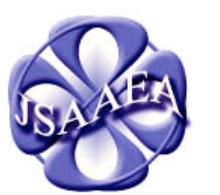

Volume 6 (2011)

\section{Journal of Southeast Asian American Education \& Advancement}

\author{
WWW.JSAAEA.org
}

\section{Editor}

Dr. Wayne E. Wright

University of Texas, San Antonio

\section{Associate Editors}

Dr. Chhany Sak-Humphry

University of Hawaii

Dr. KimOanh Nguyen-Lam

California State University, Long Beach

Book Review Editor

Dr. Vichet Chhuon

University of Minnesota

\section{Creative Works Editor}

Bryan Thao Worra

Lao Assistance Center

Special Advisor

Gregory Green

Curator, Echols Collection on Southeast Asia, Cornell University Library

\section{Journal Manager}

Sovicheth Boun

University of Texas, San Antonio
A peer-reviewed scholarly journal published by the

National Association

for the Education \&

Advancement of

Cambodian, Laotian,

and Vietnamese

Americans (NAFEA)

Comments and questions for the editorial staff may be directed to jsaaea@lists.sis.utsa.edu

\section{Editorial Review Board}

\author{
Dr. Steve Arounsack \\ California State University, Stanislaus \\ Dr. Phala Chea \\ Lowell Public Schools \\ Dr. Loan Dao \\ Cancer Prevention Institute of California \\ Dr. Sophal Ear \\ U.S. Naval Postgraduate School \\ Dr. Nancy H. Hornberger \\ University of Pennsylvania \\ Dr. Peter Nien-Chu Kiang \\ University of Massachusetts, Boston
}

Dr. Carl L. Bankston III

Tulane University

Dr. George Chigas

University of Massachusetts, Lowell

Dr. Changming Duan

University of Missouri, Kansas City

Dr. Jeremy Hein

University of Wisconsin - Eau Claire

Dr. Samlong Inthaly

Minneapolis Public Schools

Dr. Kevin K. Kumashiro

University of Illinois, Chicago 


\author{
Dr. Jonathan H. X. Lee \\ San Francisco State University \\ Dr. Sue Needham \\ California State University, Dominguez Hills \\ Dr. Max Niedzwiecki \\ Daylight Consulting Group \\ Dr. Clara Park \\ California State University, Northridge \\ Dr. Mark Pfeifer \\ Texas A\&M University, Corpus Christi \\ Dr. Loan T. Phan \\ University of New Hampshire \\ Dr. Karen Quintiliani \\ California State University, Long Beach \\ Dr. Angela Reyes \\ Hunter College, The City University of New York \\ Dr. Nancy J. Smith-Hefner \\ Boston University \\ Dr. Christine Su \\ Ohio University \\ Dr. Loan Tran \\ University of California, Riverside \\ Dr. Tinou Tran \\ Alief Independent School District \\ Dr. Phitsamay Sychitkokhong Uy \\ University of Massachusetts, Lowell \\ Dr. Terrence G. Wiley \\ Center for Applied Linguistics \\ Dr. Stacey Lee \\ University of Wisconsin, Madison \\ Dr. Bic Ngo \\ University of Minnesota \\ Dr. Leakhena Nou \\ California State University, Long Beach \\ Dr. Isabelle Thuy Pelaud \\ San Francisco State University \\ Dr. Giang Pham \\ University of Minnesota \\ Dr. Bounlieng Phommasouvanh \\ Minnesota Department of Education \\ Dr. Kalyani Rai \\ University of Wisconsin, Milwaukee \\ Dr. Fay Shin \\ California State University, Long Beach \\ Dr. Cathy J. Schlund-Vials \\ University of Connecticut, Storrs \\ Dr. Yer J. Thao \\ Portland State University \\ Dr. Myluong Tran \\ San Diego State University \\ Dr. Khatharya Um \\ University of California, Berkeley \\ Dr. Linda Trinh Vo \\ University of California, Irvine \\ Dr. Zha Blong Xiong \\ University of Minnesota \\ California State University, Stanislaus
}

\section{Doctoral Student Editorial Review Board}

\author{
Keo Chea-Young \\ University of Pennsylvania \\ Ketmani Kouanchao \\ California State University, Fullerton \\ Ha Lam \\ Arizona State University \\ Monirith Ly \\ Texas State University-San Marcos \\ Malaphone Phommasa \\ University of California, Santa Barbara \\ Rassamichanh Souryasack \\ University of California, Santa Barbara \\ Alisia Tran \\ University of Minnesota \\ Silvy Un \\ University of Minnesota
}

\author{
Annie BichLoan Duong \\ San Joaquin County Office of Education \\ Peter Tan Keo \\ Columbia University \\ Ravy Lao \\ University of California, Santa Barbara \\ Thien-Huong Ninh \\ University of Southern California \\ Vanna Som \\ Harvard University \\ Somongkol Teng \\ University of Minnesota \\ Krissyvan Truong \\ Claremount Graduate University \\ Yang Sao Xiong \\ University of California, Los Angeles
}

Yeng Yang

University of Texas, San Antonio 